\title{
A nitrate-permeable ion channel in the tonoplast of the moss Physcomitrella patens
}

\author{
Mateusz Koselski $\cdot$ Halina Dziubinska $\cdot$ \\ Aleksandra Seta-Koselska $\cdot$ Kazimierz Trebacz
}

Received: 23 October 2014/ Accepted: 19 January 2015/Published online: 1 February 2015

(C) The Author(s) 2015. This article is published with open access at Springerlink.com

\begin{abstract}
Main conclusion In this work, for the first time the activity of nitrate-permeable channels in the tonoplast of the moss Physcomitrella patens was recorded. The channels allowed nitrate flow in one direction-from the cytoplasm to the vacuole. Selectivity of nitrate over chloride of the channels was proved. The activity of the channels was dependent on cytoplasmic calcium, magnesium, and $\mathrm{pH}$.

A patch-clamp study carried out on the vacuolar membrane of the moss Physcomitrella patens has revealed that inhibition of cation-selective channels leads to disclosure of channels permeable to $\mathrm{NO}_{3}{ }^{-}$. These channels were inwardly rectifying and allowed anions to flow from the cytoplasm to the vacuole. After a decrease in the cytoplasmic $\mathrm{NO}_{3}{ }^{-}$concentration, the current density recorded in the whole-vacuole configuration and amplitude of the currents flowing through single channels were reduced. Application of the $\mathrm{NO}_{3}{ }^{-}$gradient caused a shift in the reversal potential $\left(\mathrm{E}_{\mathrm{rev}}\right)$ towards $\mathrm{E}_{\mathrm{NO} 3-}$, indicating $\mathrm{NO}_{3}{ }^{-}$ permeability. Research of the selectivity of the channels to $\mathrm{Cl}^{-}$and $\mathrm{NO}_{3}{ }^{-}$was also done; it indicated that $\mathrm{Cl}^{-}$is less
\end{abstract}

Electronic supplementary material The online version of this article (doi:10.1007/s00425-015-2250-3) contains supplementary material, which is available to authorized users.

M. Koselski $(\bowtie) \cdot$ H. Dziubinska · K. Trebacz

Department of Biophysics, Institute of Biology and

Biochemistry, Maria Curie-Skłodowska University,

Akademicka 19, 20-033 Lublin, Poland

e-mail: mateusz.koselski@poczta.umcs.lublin.pl

\section{A. Seta-Koselska}

Department of Plant Physiology and Biotechnology, Institute of Biotechnology, The John Paul II Catholic University of Lublin, Konstantynow 1i, 20-708 Lublin, Poland permeable than $\mathrm{NO}_{3}{ }^{-}\left(\mathrm{P}_{\mathrm{NO} 3} / \mathrm{P}_{\mathrm{Cl}}=3.08\right)$. Measurements with different concentrations of cytoplasmic $\mathrm{Ca}^{2+}$ and $\mathrm{Mg}^{2+}$ revealed that the channel was activated by different concentrations of these ions- $100 \mu \mathrm{M} \mathrm{Ca}{ }^{2+}$ and $10 \mathrm{mM} \mathrm{Mg}^{2+}$. Calcium dependence of the channels was also modulated by a redox agent-DTT (dithiothreitol), which added on the cytoplasmic side, caused a reduction in the threshold of channel activation with cytoplasmic $\mathrm{Ca}^{2+}$. The $\mathrm{NO}_{3}{ }^{-}$permeable channel was also $\mathrm{pH}$ dependent. A decrease in the cytoplasmic $\mathrm{pH}$ reduced the open probability of the channel; in turn, an increase in the vacuolar $\mathrm{pH}$ did not decrease ion channel activity but lowered its conductance.

Keywords Anion channels · Patch-clamp ·

Physcomitrella $\cdot$ Vacuole

\begin{tabular}{ll}
\multicolumn{2}{l}{ Abbreviations } \\
ALMT & Aluminium-activated malate transporter \\
BTP & Bis-tris propane \\
CAM & Crassulacean acid metabolism \\
CDPK & Calcium-dependent protein kinase \\
ClC & Chloride channel \\
DTT & Dithiothreitol \\
EGTA & Ethylene glycol tetraacetic acid \\
ENO3 & Reversal potential for nitrate \\
NRT & Nitrate transporter \\
SV & Slowly activating vacuolar channel \\
TRP & Transient receptor potential \\
VK & Vacuolar $\mathrm{K}^{+}$channel
\end{tabular}

Introduction

The tonoplast (vacuolar membrane) surrounding the largest, centrally located plant cell organelle (vacuole) is the 
object of electrophysiological investigations. Vacuoles are involved in maintenance of turgor in cells and accumulation of various molecules important for normal functioning of plant cells. Exchange of ions and substances between the vacuole and cytosol is achieved through ion channels, pumps, and transporters. The simplicity of vacuole isolation and the size of these objects facilitate application of different electrophysiological techniques, including the patch-clamp technique. This technique allows analysis of ion fluxes through ion channels located in the tonoplast. This method was employed in investigations of many types of ion channels in tonoplasts of various plants, primarily cation channels, and their function in the cell. There are considerably fewer papers concerning anion channels in the tonoplast, although the channels play an equally important role in osmoregulation, signalling, and maintenance of cell homeostasis. An important group of proteins involved in anion transport is represented by a family of chloride channels (CLCs) located in cell membranes in both prokaryotes and eukaryotes. Among the wide family of these transporters, some are chloride channels, like $\mathrm{ClC}$ 0 found in the torpedo-fish (Miller and White 1980) and mammalian ClC-1 (Steinmeyer et al. 1991), whereas others like ClC-ecl from Escherichia coli (Accardi and Miller 2004) and mammalian ClC-4 and ClC-5 (Picollo and Pusch 2005) are known as $\mathrm{Cl}^{-} / \mathrm{H}^{+}$exchangers.

CLC genes were the first identified genes encoding anion channels in Nicotiana tabacum (Lurin et al. 1996) and Arabidopsis (Hechenberger et al. 1996). Four novel members of the CLC family cloned in Arabidopsis are homologous to the chloride channel gene (CLC-NtI) from tobacco (Lurin et al. 1996). Similarly, OsCLC1 and OsCLC2 genes, which encode the proteins of chloride channels in vacuolar membranes in rice, were found to be homologous to the tobacco CLC-Nt1 gene (Nakamura et al. 2006). Another gene ( $G m C L C 1$ ) encodes a chloride channel localised in the soybean tonoplast (Li et al. 2006).

Currently, seven genes encoding CLC proteins serving the function of anion channels or transporters have been identified in the genome of Arabidopsis (Hechenberger et al. 1996; Marmagne et al. 2007; Lv et al. 2009; von der Fecht-Bartenbach et al. 2010). The AtCLCa protein located in the vacuole acts as a proton-nitrate exchanger. It contributes up to 50-fold increase in nitrate accumulation in the vacuole relative to the cytoplasm (De Angeli et al. 2006). Achievement of such a high nitrate gradient would not be possible at passive transport through the channels. Patch-clamp investigations have shown that AtCLCa acts in the tonoplast as an exchanger mediating an influx of two nitrate anions into the vacuole and an efflux of one proton from the vacuole into the cytoplasm. The vacuolar $\mathrm{H}^{+}$/ $\mathrm{NO}_{3}{ }^{-}$exchanger properties are also exhibited by AtCLCb; however, in the case of this protein, the exact coupling ratio has not been yet determined (von der Fecht-Bartenbach et al. 2010). The vacuolar location of two other proteins, AtCLCc and AtCLCg, has been experimentally evidenced (Lv et al. 2009; Jossier et al. 2010), but there is still lack of data allowing classification of these proteins to a particular type of transporters-anion channels and $\mathrm{H}^{+} / \mathrm{Cl}^{-}$or $\mathrm{H}^{+} /$ $\mathrm{NO}_{3}{ }^{-}$exchangers. The well-known X-ray structure of the ClC-ec1 homologue can be helpful for qualification of these two proteins to channels or to exchangers (Accardi and Miller 2004; Accardi et al. 2005). According to this research, one of the two glutamic acid residues (E203) present in all known CLC exchangers (including AtCLCa$\mathrm{d}, \mathrm{g}$ ) is required for proton exchange and is proposed to be a mark for distinguishing channels from exchangers.

Considering the ways of nitrate uptake by plant cells, one member of NRT2 (NitRate Transporter) family should be mentioned-NRT2.7. In Arabidopsis thaliana, this transporter (AtNRT2.7) is located in the tonoplast of seeds and takes part in nitrate loading into the vacuole (Chopin et al. 2007).

Knowledge of the basis of anion transport and anion selectivity in plant tonoplasts at different systematic levels will allow determination of the evolution of anion transport systems. Physcomitrella patens, a plant with a fully identified genome and with a systematic position between bacteria and higher plants, would be a useful link in tracing possible changes in anion transport through the tonoplast.

\section{Materials and methods}

\section{Plant material}

A moss Physcomitrella patens, obtained by courtesy of Prof. Dr. Ralf Reski (University of Freiburg, Germany), was grown in a growth chamber at $22{ }^{\circ} \mathrm{C}$ with light intensity of $60 \mu \mathrm{mol} \mathrm{m} \mathrm{m}^{-2} \mathrm{~s}^{-1}$ under a $16 / 8 \mathrm{~h}$ light/dark photoperiod. The cultivation of the moss was carried out in Petri dishes filled with solid KNOP medium (Reski and Abel 1985). The moss culture was maintained by passaging of gametophytes into a fresh medium.

\section{Vacuole isolation}

Vacuoles were isolated using a non-enzymatic method described by Trebacz and Schönknecht (2000). Before the experiments, leaves of the gametophytes were placed in a plasmolysing medium containing $650 \mathrm{mM}$ sorbitol and different ions, depending on the experiment. After 20-30 min, several leaves were cut and placed in the measuring chamber containing a solution with lower than earlier osmotic pressure (about $350 \mathrm{mOsm} \mathrm{kg}^{-1}$ ). Deplasmolysis of the cells caused release of a few protoplasts 
from the cutting-destroyed cell walls. After a few minutes, some of the protoplasts ruptured which allowed release of the vacuoles.

\section{Patch-clamp experiments}

The experiments were carried out in two patch-clamp configurations-whole-vacuole and cytoplasm-out. The micropipettes made from borosilicate tubes (Kwik-Fil TW150-4; WPI, Sarasota, FL, USA) were pulled and polished by a DMZ-Universal Puller (Zeitz-Instruments, Martinsried, Germany). An $\mathrm{Ag} / \mathrm{AgCl}$ reference electrode was filled with $100 \mathrm{mM} \mathrm{KCl}$ and contacted with the bath solution by a ceramic porous bridge. Osmolarity of the solutions was checked using a cryoscopic osmometer (Osmomat 030; Gonotec, Berlin, Germany). The experiments were recorded using an EPC-10 amplifier (Heka Electronik, Lambrecht, Germany), running with the Patchmaster software (Heka Electronik). The sample frequency was $10 \mathrm{kHz}$ with a $2 \mathrm{kHz}$ filter. The sign of the tonoplast voltage was the same as that proposed by Bertl et al. (1992). The bath solutions were exchanged before recording using a peristaltic pump (ISM796B; Ismatec, Wertheim, Germany). The values of voltages applied in the experiments include the magnitude of the liquid junction potentials measured according to the method described by Amtmann and Sanders (1997).

\section{Analysis of the results}

Current/voltage (I/V) and current density/voltage (J/V) characteristics were made in SigmaPlot 9.0 (Systat Software Inc.). The Gaussian fits of the histograms were made in GRAMS/AI 8.0 (Spectroscopy Software). The area under the Gaussian peaks was used in calculations of the channel open probability. Ion activities were taken into account in calculations of the reversal potentials for the ions $\left(\mathrm{E}_{\mathrm{rev}}\right)$. Activities of the ions were also used in calculations of the permeability ratio obtained from the Goldman-Hodgkin-Katz equation. Due to lack of linear characteristics of the I/V curves, the unitary conductance of the channels was calculated as a current/voltage ratio determined at the most extreme voltage applied. The number of the experimental repeats $(n)$ indicates the number of tested vacuoles or tonoplast patches.

\section{Solution composition}

Solutions used for recording the SV channels contained $200 \mathrm{mM} \mathrm{NaNO}{ }_{3}, 2 \mathrm{mM} \mathrm{CaCl}_{2}, 2 \mathrm{mM} \mathrm{MgCl}$, pH 7 (buffered by HEPES/TRIS) on the cytoplasmic side and $200 \mathrm{mM} \mathrm{NaNO}, 2 \mathrm{mM} \mathrm{CaCl}_{2}, 2 \mathrm{mM} \mathrm{MgCl}$, pH 5 (buffered by MES/TRIS) on the vacuolar side. Reduction of currents carried by SV channels was achieved by replacement of the solution on the cytoplasmic side with $200 \mathrm{mM}$ $\mathrm{HNO}_{3}, 2 \mathrm{mM} \mathrm{CaCl} 2,2 \mathrm{mM} \mathrm{MgCl} 2$ (buffered by $160 \mathrm{mM}$ BTP). $\mathrm{NO}_{3}{ }^{-}$permeable channels were recorded in solutions containing $200 \mathrm{mM} \mathrm{HNO}_{3}, 2 \mathrm{mM} \mathrm{CaCl} 2,2 \mathrm{mM}$ $\mathrm{MgCl}_{2}$, pH 5 (buffered by $101 \mathrm{mM}$ BTP) on the vacuolar side, and $200 \mathrm{mM} \mathrm{HNO}_{3}, 2 \mathrm{mM} \mathrm{CaCl}_{2}, 2 \mathrm{mM} \mathrm{MgCl}_{2}, \mathrm{pH}$ 7 (buffered by $160 \mathrm{mM}$ BTP). The selectivity of the channels was studied by replacement of the solution on the cytoplasmic side with $20 \mathrm{mM} \mathrm{HNO}_{3}, 2 \mathrm{mM} \mathrm{CaCl}_{2}, 2 \mathrm{mM}$ $\mathrm{MgCl}_{2}$, pH 7 (buffered by $16 \mathrm{mM}$ BTP). Solutions on the cytoplasmic side were also replaced in measurements of the dependence of the channel activity on cytoplasmic $\mathrm{Ca}^{2+}$ and $\mathrm{Mg}^{2+}$ and $\mathrm{pH} . \mathrm{Ca}^{2+}$ and $\mathrm{Mg}^{2+}$ dependence was studied in $200 \mathrm{mM} \mathrm{HNO}_{3}, 2 \mathrm{mM}$ EGTA, $2 \mathrm{mM} \mathrm{MgCl}$, pH 7 (buffered by $148 \mathrm{mM}$ BTP) mixed with a suitable amount of $\mathrm{CaCl}_{2}$ or $\mathrm{MgCl}_{2}$, the concentrations of which were calculated in Ca-EGTA Calculator v1.3 (http://max chelator.stanford.edu/CaEGTA-TS.htm) and Ca-Mg-ATPEGTA Calculator v1.0 (http://maxchelator.stanford.edu/ CaMgATPEGTA-NIST.htm), respectively. Measurements of $\mathrm{pH}$ dependence were carried out in $200 \mathrm{mM} \mathrm{HNO}_{3}$, $2 \mathrm{mM} \mathrm{CaCl}_{2}, 2 \mathrm{mM} \mathrm{MgCl}$, buffered by $131 \mathrm{mM} \mathrm{BTP}(\mathrm{pH}$ 6.5 ) or by $113 \mathrm{mM}$ BTP (pH 6.0). The experiments aimed at determination of $\mathrm{Cl}^{-}$over $\mathrm{NO}_{3}{ }^{-}$selectivity were begun in $200 \mathrm{mM} \mathrm{HCl}, 2 \mathrm{mM} \mathrm{CaCl}, 2 \mathrm{mM} \mathrm{MgCl} 2$, pH 5 (buffered by $82 \mathrm{mM} \mathrm{BTP}$ ) on the vacuolar side and $200 \mathrm{mM}$ $\mathrm{HCl}, 2 \mathrm{mM} \mathrm{CaCl}, 2 \mathrm{mM} \mathrm{MgCl}_{2}$, pH 7 (buffered by $128 \mathrm{mM}$ BTP) on the cytoplasmic side. Next, the solution on the cytoplasmic side was replaced with $200 \mathrm{mM} \mathrm{HNO}_{3}$, $2 \mathrm{mM} \mathrm{CaCl} 2,2 \mathrm{mM} \mathrm{MgCl}_{2}$, pH 7 (buffered by $160 \mathrm{mM}$ BTP).

\section{Results}

In our previous study (Koselski et al. 2013), we demonstrated that two different cation-selective channels were active in the vacuole of the moss Physcomitrella patens$\mathrm{SV}$ channels permeable to $\mathrm{Na}^{+}, \mathrm{K}^{+}, \mathrm{Ca}^{2+}, \mathrm{Mg}^{2+}$, and $\mathrm{K}^{+}$- selective $\mathrm{VK}$ channels. In the present study, we reduced the activity of SV and VK channels by elimination of cations which can flow through these channels. Since there are reports on plant vacuolar anion channels indicating higher permeability to $\mathrm{NO}_{3}{ }^{-}$than to $\mathrm{Cl}^{-}$(De Angeli et al. 2006; von der Fecht-Bartenbach et al. 2010), we used $\mathrm{NO}_{3}{ }^{-}$as the main anion.

The first step in our research was studying the effect of SV channel activity reduction by replacement of cytoplasmic $200 \mathrm{mM} \mathrm{NaNO} 3$ with $200 \mathrm{mM} \mathrm{HNO}_{3}$ (Fig. 1). Together with elimination of cytoplasmic $\mathrm{Na}^{+}$, we also decided to reduce SV channel activity using BTP-an impermeable cation-as a buffer. In the whole-vacuole 
configuration, elimination of cytoplasmic $\mathrm{Na}^{+}$caused reduction of currents carried by $\mathrm{SV}$ channels (from $1.06 \pm 0.21 \mathrm{~A} / \mathrm{m}^{2}$ recorded at $+80 \mathrm{mV}, \quad n=4$ to $0.05 \pm 0.02 \mathrm{~A} / \mathrm{m}^{2}$ recorded at $+86 \mathrm{mV}, n=4$ ) but also an increase in the current density recorded at negative voltages (from $0.09 \pm 0.01 \mathrm{~A} / \mathrm{m}^{2}$ recorded at $-100 \mathrm{mV}, n=4$ to $0.2 \pm 0.05 \mathrm{~A} / \mathrm{m}^{2}$ recorded at $\left.-94 \mathrm{mV}, n=4\right)$. The above-mentioned phenomenon was caused by changes in the number of active ion channels, which was confirmed by the single channel recordings carried out in the cytoplasmout configuration (Fig. 2). The amplitude histograms based on the recordings obtained at $+40 \mathrm{mV}$, which correspond to the activity of SV channels (Fig. 2c) showed complete

(a)

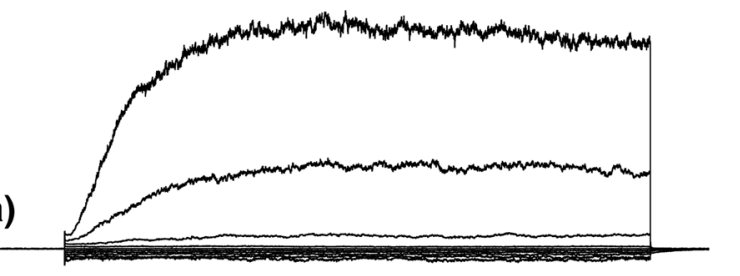

$$
1 \mathrm{nA}
$$

$1 \mathrm{~s}$

(b)

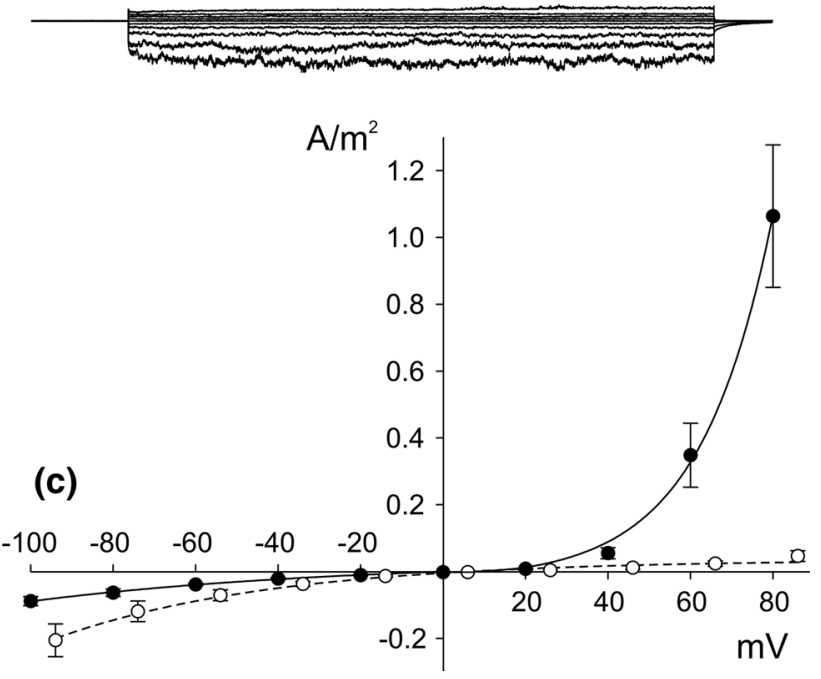

Fig. 1 Activation of negative currents concomitant with reduction of SV channels activity. a Example of whole-vacuole recordings obtained in $200 \mathrm{mM} \mathrm{NaNO}$, $2 \mathrm{mM} \mathrm{CaCl}_{2}, 2 \mathrm{mM} \mathrm{MgCl}$, pH 7 (buffered by HEPES/TRIS) in the bath and $200 \mathrm{mM} \mathrm{NaNO}_{3}, 2 \mathrm{mM}$ $\mathrm{CaCl}_{2}, 2 \mathrm{mM} \mathrm{MgCl}$, pH 5 (buffered by MES/TRIS) in the pipette. b Recordings obtained on the same vacuole as in a after replacement of the bath solution with $200 \mathrm{mM} \mathrm{HNO}_{3}, 2 \mathrm{mM} \mathrm{CaCl}_{2}, 2 \mathrm{mM} \mathrm{MgCl}$, pH 7 buffered by $160 \mathrm{mM}$ BTP. c J/V curves obtained in the same conditions as in $\mathbf{a}$ (closed circles and solid line, $n=4$ ) and $\mathbf{b}$ (open circles and dashed line, $n=4)$, respectively. Recordings were obtained by application of $0.5 \mathrm{~s}$ holding voltage $(0 \mathrm{mV}$ for $\mathbf{a}$ and $6 \mathrm{mV}$ for b), then $3 \mathrm{~s}$ test voltages with $20 \mathrm{mV}$ steps (from -100 to $80 \mathrm{mV}$ for $\mathbf{a}$ and from -94 to $86 \mathrm{mV}$ for $\mathbf{b})$, and $0.3 \mathrm{~s}$ pulse $(0 \mathrm{mV}$ for $\mathbf{a}$ and $6 \mathrm{mV}$ for $\mathbf{b}$ ) after test voltage reduction of the channel activity after replacement of $\mathrm{NaNO}_{3}$ with $\mathrm{HNO}_{3}$. In turn, at negative voltages, the lack of $\mathrm{Na}^{+}$on the cytoplasmic side revealed activation of ion currents (Fig. 2b, d). The amplitude histograms based on the recordings of the channels at $-74 \mathrm{mV}$ in the absence of cytoplasmic $\mathrm{Na}^{+}$(Fig. 2d, lower histogram) and $\mathrm{SV}$ channels recorded at $+40 \mathrm{mV}$ in the presence of cytoplasmic $\mathrm{Na}^{+}$(Fig. 2c, upper histogram) allow determination of the number of channels active in one patch and also an open probability and unitary conductance. The average number of SV channels active in one patch $($ at $+40 \mathrm{mV})$ was higher than that of the other channels active at $-74 \mathrm{mV}$ (4 channels in respect to 1 ). The number of active channels did not reflect the open probability, because this parameter was similar for both channels $(0.21$ for $\mathrm{SV}$ channels recorded at $+40 \mathrm{mV}$ and 0.25 for channels recorded at $-74 \mathrm{mV}$ ). A comparison of the differences between the positions of the Gaussian peak centres indicated different unitary conductance of the channels, which at $-74 \mathrm{mV}$ reached $86.75 \mathrm{pS}$ and at $+40 \mathrm{mV}$ $-72.75 \pm 0.11 \mathrm{pS}(n=4)$.

The whole-vacuole recordings obtained in symmetrical (in the patch pipette and in the medium) concentrations of $\mathrm{NO}_{3}{ }^{-}$allowed observation of inward rectification and slow activation of the channels (Fig. 3a). The amplitude of the whole-vacuole currents was dependent on the cytoplasmic concentration of $\mathrm{NO}_{3}{ }^{-}$, which after tenfold reduction, caused a decrease in the negative currents from $0.27 \pm 0.06$ $\mathrm{A} / \mathrm{m}^{2}$ recorded at $-100 \mathrm{mV}(n=5)$ to $0.04 \pm 0.02 \mathrm{~A} / \mathrm{m}^{2}$ recorded at $-108 \mathrm{mV}(n=5)$ (Fig. 3b, c). Besides the changes in the whole-vacuole current amplitudes, there was also a shift in the reversal potential towards the equilibrium potential for $\mathrm{NO}_{3}{ }^{-}\left(\mathrm{E}_{\mathrm{NO}}\right)$ (Fig. 3c), although determination of the reversal potential in this configuration was inaccurate due to strong rectification. The decrease in the whole-vacuole currents was caused by a decrease in the current flowing through a single channel, confirmed by the cytoplasm-out recordings (Fig. 3d, e, f). The value of the channel conductance decreased from $95.5 \pm 1.37 \mathrm{pS}$ recorded at $-80 \mathrm{mV}(n=6)$ to $29.12 \pm 0.87 \mathrm{pS}$ recorded at $-88 \mathrm{mM}(n=6)$. The cytoplasm-out recordings carried out in the $\mathrm{NO}_{3}{ }^{-}$gradient confirmed $\mathrm{NO}_{3}{ }^{-}$permeability of the channels because the reversal potential obtained from the $\mathrm{I} / \mathrm{V}$ curve was shifted towards $\mathrm{E}_{\mathrm{NO} 3}$ (whose value in the gradient of $\mathrm{NO}_{3}{ }^{-}$amounts to $-51.6 \mathrm{mV}$ ) from 3.5 to $-34.9 \mathrm{mV}$ (Fig. 3f). The cytoplasm-out recordings also showed dependence of single channel open probability on the cytoplasmic $\mathrm{NO}_{3}{ }^{-}$concentration. At $200 \mathrm{mM}$ cytoplasmic $\mathrm{NO}_{3}{ }^{-}$, the open probability of single channels reached 0.39 at $-80 \mathrm{mV}$ and dropped to 0.19 at $-88 \mathrm{mV}$ after tenfold reduction of the $\mathrm{NO}_{3}{ }^{-}$concentration (Supplementary Material). The decrease in the open probability recorded at the low cytoplasmic $\mathrm{NO}_{3}{ }^{-}$concentration can be 
(a)

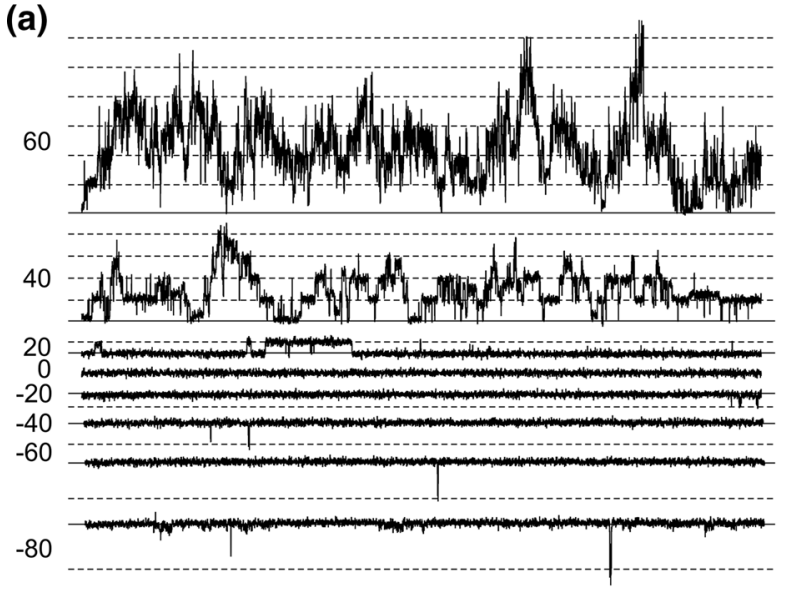

(b)
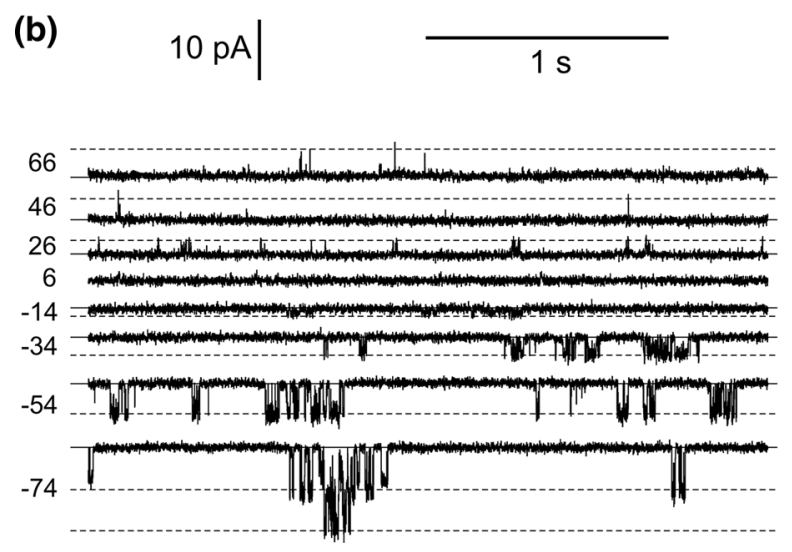

Fig. 2 Activation of ion currents recorded at negative voltages concomitant with reduction of SV currents. a Example of cytoplasmout recordings obtained in $200 \mathrm{mM} \mathrm{NaNO}, 2 \mathrm{mM} \mathrm{CaCl}_{2}, 2 \mathrm{mM}$ $\mathrm{MgCl}_{2}$, pH 7 (buffered by HEPES/TRIS) in the bath and $200 \mathrm{mM}$ $\mathrm{NaNO}_{3}, 2 \mathrm{mM} \mathrm{CaCl} 2,2 \mathrm{mM} \mathrm{MgCl}$, pH 5 (buffered by MES/TRIS) in the pipette. The solid line indicates the closed state of the channels and the dashed line the open states. Values of holding voltages were placed on the left side of the traces. b Recordings obtained on the same vacuole as in a after replacement of bath solution with $200 \mathrm{mM}$ $\mathrm{HNO}_{3}, 2 \mathrm{mM} \mathrm{CaCl}, 2 \mathrm{mM} \mathrm{MgCl}$, pH 7 buffered by $160 \mathrm{mM} \mathrm{BTP.}$

explained by a shift of the activation voltage toward negative voltages.

Besides $\mathrm{NO}_{3}{ }^{-}$, also $\mathrm{Cl}^{-}$permeability of the channels was studied. In the symmetrical concentration of these anions (Fig. 4a), as in the case of symmetrical $\mathrm{NO}_{3}{ }^{-}$, channel activity was recorded only at negative voltages. The unitary conductance of the channels at $-80 \mathrm{mV}$ equalled $108.1 \pm 1.3 \mathrm{pS}(n=5)$. This value was close to the unitary conductance obtained in the symmetrical concentration of $\mathrm{NO}_{3}{ }^{-}$, which reached $95.5 \pm 1.4 \mathrm{pS}$ at $-80 \mathrm{mV}(n=6)$. To study $\mathrm{Cl}^{-} / \mathrm{NO}_{3}{ }^{-}$selectivity during cytoplasm-out recordings, $\mathrm{Cl}^{-}$was replaced with $\mathrm{NO}_{3}{ }^{-}$(Fig. 4b). In such conditions, a shift in the reversal potential to positive values was observed (from -0.2 to $26.6 \mathrm{mV}$, Fig. 4c), indicating $\mathrm{NO}_{3}{ }^{-}$over $\mathrm{Cl}^{-}$selectivity. The $\mathrm{NO}_{3}{ }^{-} / \mathrm{Cl}^{-}$permeability (c)

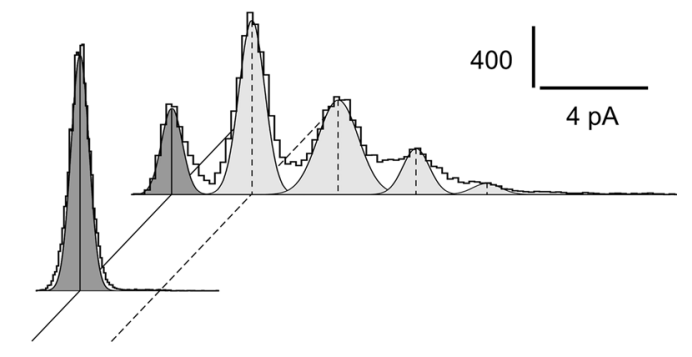

(d)

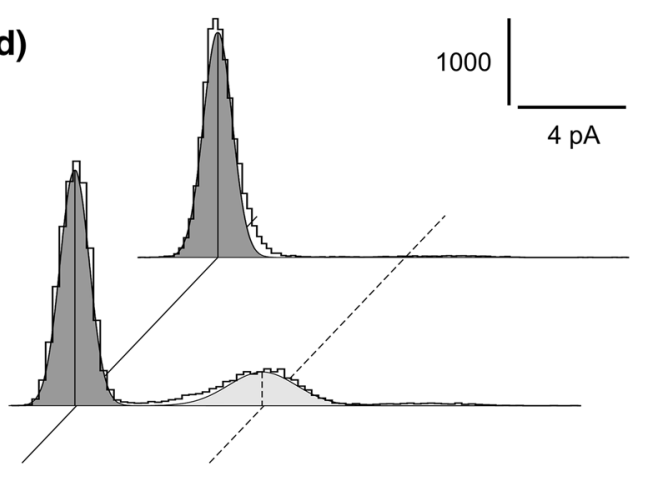

c Amplitude histograms indicating the number of sample points (vertical bar) and a certain current amplitude (horizontal bar), based on recordings from four patches obtained at $+40 \mathrm{mV}$ in conditions as in a (upper histogram) and at $+46 \mathrm{mV}$ in conditions as in $\mathbf{b}$ (lower histogram), respectively. The diagonal solid line indicates the closed state, and the dashed line the open state. d Amplitude histograms based on recordings from four patches obtained at $-80 \mathrm{mV}$ in conditions as in a (upper histogram) and b (lower histogram), respectively

ratio of the channels determined by the Goldman-HodgkinKatz equation amounted to 3.08 .

The activity of the $\mathrm{NO}_{3}{ }^{-}$permeable channels was dependent on cytoplasmic $\mathrm{Ca}^{2+}$ and $\mathrm{Mg}^{2+}$. The dependence of the channels on cytoplasmic $\mathrm{Ca}^{2+}$ was studied at 10 and $100 \mu \mathrm{M}$ concentrations of this ion (Fig. 5a, b, c). Changes in the cytoplasmic $\mathrm{Ca}^{2+}$ concentration from 100 to $10 \mu \mathrm{M}$ caused reduction of the channel activity by decreasing the open probability from 0.28 to 0.02 (Fig. 5c). The calcium sensitivity of the channel was modulated by cytoplasmic DTT (Fig. 5d, e, f) - a reducing agent that is effective in activation of voltage- and calcium-dependent channels including plant SV channels (Carpaneto et al. 1999; Paganetto et al. 2001; Scholz-Starke et al. 2004). Application of $1 \mathrm{mM}$ DTT on the cytoplasmic side caused 
(a)

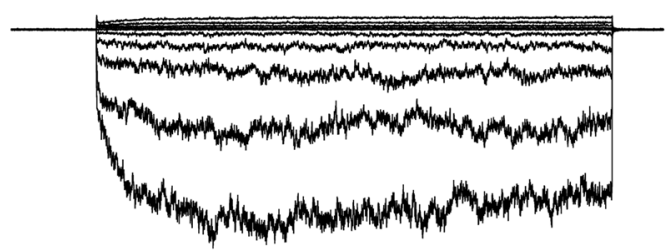

(b)

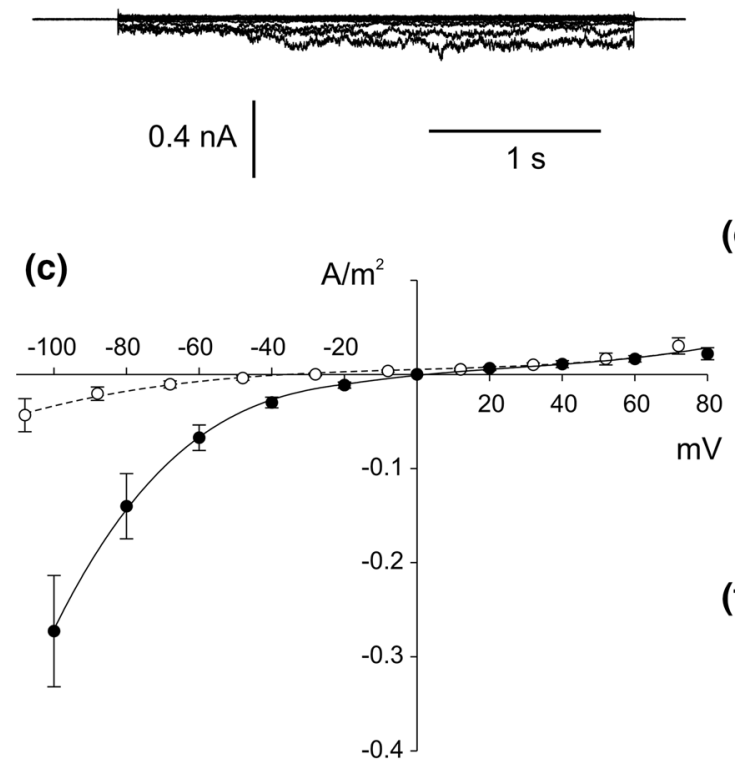

(d)

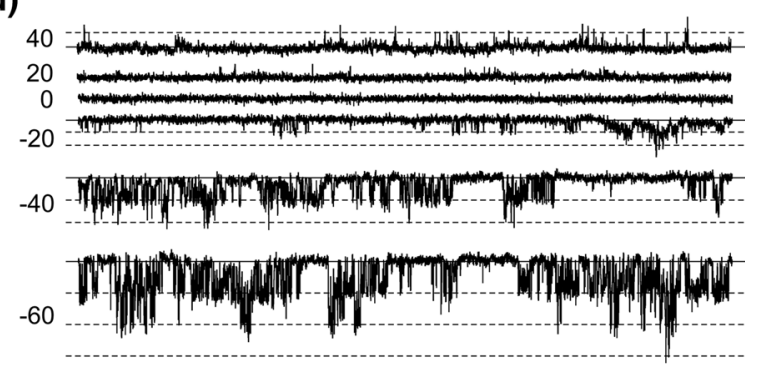

(e)

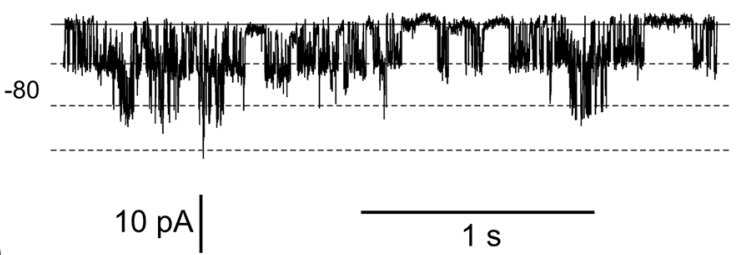

(f)

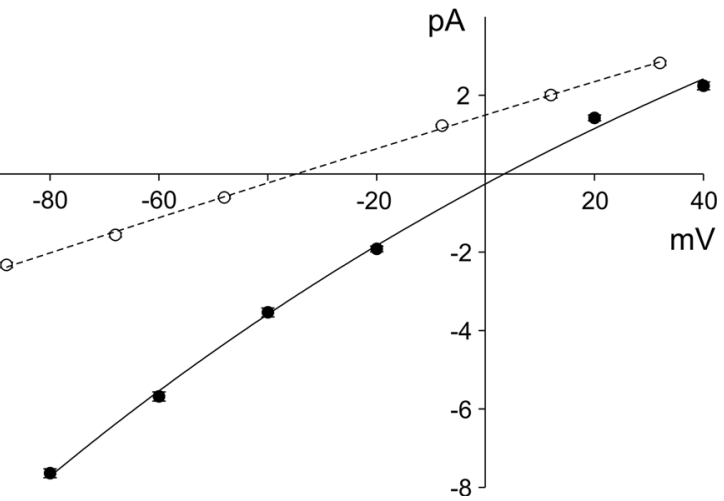

Fig. 3 Activity of negative currents at different cytoplasmic $\mathrm{HNO}_{3}$ concentrations. a Whole-vacuole currents obtained in $200 \mathrm{mM}$ $\mathrm{HNO}_{3}, 2 \mathrm{mM} \mathrm{CaCl} 2,2 \mathrm{mM} \mathrm{MgCl}$, pH 7 (buffered by $160 \mathrm{mM}$ BTP) in the bath and $200 \mathrm{mM} \mathrm{HNO}_{3}, 2 \mathrm{mM} \mathrm{CaCl}_{2}, 2 \mathrm{mM} \mathrm{MgCl}_{2}, \mathrm{pH}$ 5 (buffered by $101 \mathrm{mM} \mathrm{BTP)} \mathrm{in} \mathrm{the} \mathrm{pipette.} \mathrm{b} \mathrm{Whole-vacuole}$ currents obtained after replacement of the bath solution with $20 \mathrm{mM}$ $\mathrm{HNO}_{3}, 2 \mathrm{mM} \mathrm{CaCl}, 2 \mathrm{mM} \mathrm{MgCl}$, $\mathrm{pH} 7$ (buffered by $16 \mathrm{mM} \mathrm{BTP}$ ). c $\mathrm{J} / \mathrm{V}$ curves obtained in the same conditions as in a (closed circles and solid line, $n=5$ ) and $\mathbf{b}$ (open circles and dashed line, $n=5$ ),

an increase in the open probability recorded in the presence of $10 \mu \mathrm{M}$ cytoplasmic $\mathrm{Ca}^{2+}$ (Fig. 5d) from 0.02 (Fig. 5c, lower histogram) to 0.13 (Fig. 5f, upper histogram). The presence of cytoplasmic DTT was not sufficient to maintain the channel activity after reduction of the cytoplasmic $\mathrm{Ca}^{2+}$ concentration to $1 \mu \mathrm{M}$ (Fig. 5e), resulting in a decrease in the open probability to 0.01 (Fig. $5 \mathrm{f}$, lower histogram). The results show that under the experimental conditions used here, cytoplasmic $\mathrm{Ca}^{2+}$ activates the channels in a non-physiological concentration, because the $\mathrm{Ca}^{2+}$ concentration in the cytoplasm of plant cells is

respectively. d, e Cytoplasm-out recordings obtained under the same conditions as in $\mathbf{a}$ and $\mathbf{b}$, respectively. $\mathbf{f} \mathrm{I} / \mathrm{V}$ curves obtained under the same conditions as in $\mathbf{d}$ (closed circles and solid line, $n=6$ ) and e (open circles and dashed line, $n=6$ ), respectively. Whole-vacuole recordings were obtained by application of $0.5 \mathrm{~s}$ holding voltage $(0 \mathrm{mV}$ in $\mathbf{a}$ and $-8 \mathrm{mV}$ in b), then $3 \mathrm{~s}$ test voltages with $20 \mathrm{mV}$ steps (from -100 to $80 \mathrm{mV}$ in a and from -108 to $72 \mathrm{mV}$ in $\mathbf{b}$ ), and $0.3 \mathrm{~s}$ pulse $(0 \mathrm{mV}$ in $\mathbf{a}$ and $-8 \mathrm{mV}$ in $\mathbf{b})$ after test voltage

typically maintained at approx. $200 \mathrm{nM}$ (Bush 1995). In contrast to $\mathrm{Ca}^{2+}$, cytoplasmic $\mathrm{Mg}^{2+}$ acts on the channel activity in a physiological range of concentrations (Fig. 6), since this ion occurs in the cytoplasm of leaf cells from higher plants at concentrations from 2 to $10 \mathrm{mM}$ (Leigh and Wyn Jones 1986). The measurements with 2 and $10 \mathrm{mM} \mathrm{Mg}^{2+}$ proved that the $10 \mathrm{mM}$ concentration of this ion was efficient to activate the channels. In such concentrations, the open probability of the channels amounted to 0.36 and was reduced to 0.012 in the presence of $2 \mathrm{mM} \mathrm{Mg}^{2+}$ (Fig. 6c). 
(a)
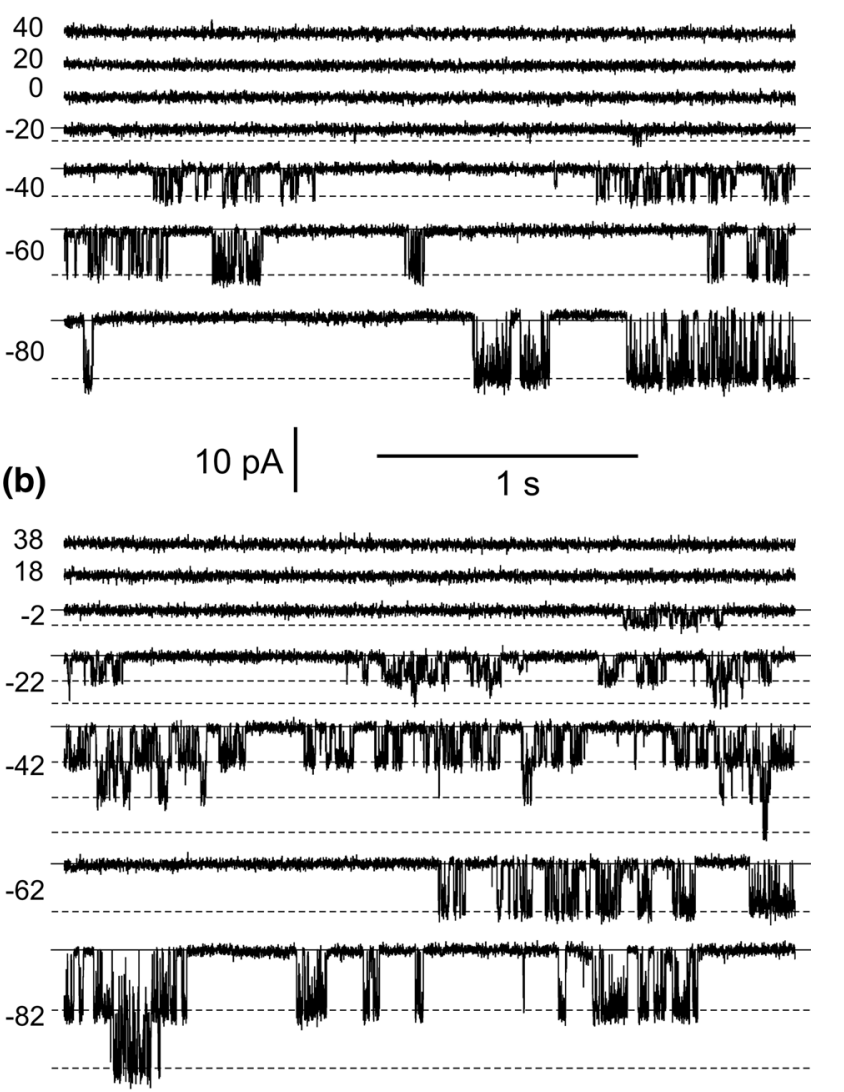

(c)

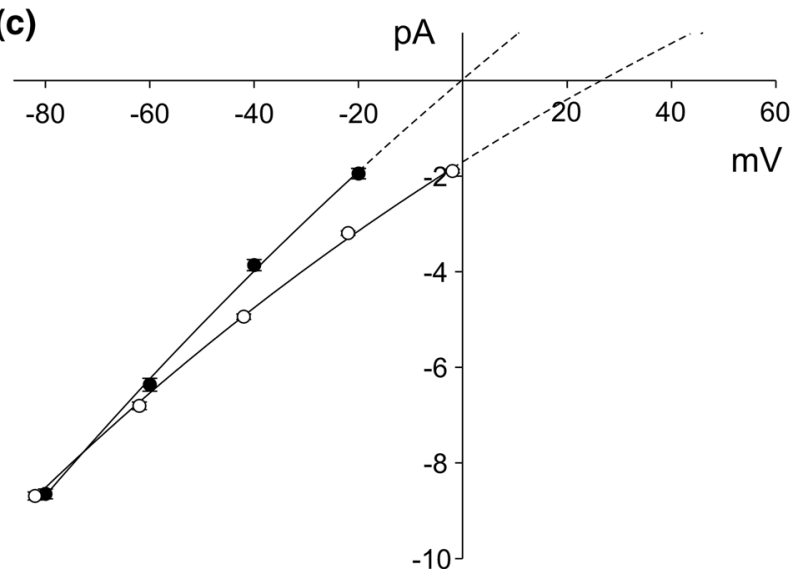

Fig. $4 \mathrm{NO}_{3}{ }^{-}$over $\mathrm{Cl}^{-}$selectivity of the channels. a Cytoplasm-out recordings obtained in $200 \mathrm{mM} \mathrm{HCl}, 2 \mathrm{mM} \mathrm{CaCl}_{2}, 2 \mathrm{mM} \mathrm{MgCl}$, $\mathrm{pH}$ 7 (buffered by $128 \mathrm{mM} \mathrm{BTP}$ ) in the bath and $200 \mathrm{mM} \mathrm{HCl}, 2 \mathrm{mM}$ $\mathrm{CaCl}_{2}, 2 \mathrm{mM} \mathrm{MgCl} 2$, pH 5 (buffered by $82 \mathrm{mM} \mathrm{BTP}$ ) in the pipette. b Cytoplasm-out recordings obtained after replacement of the bath solution with $200 \mathrm{mM} \mathrm{HNO}_{3}, 2 \mathrm{mM} \mathrm{CaCl} 2,2 \mathrm{mM} \mathrm{MgCl}$, pH 7 (buffered by $160 \mathrm{mM} \mathrm{BTP).} \mathrm{c} \mathrm{I/V} \mathrm{curves} \mathrm{obtained} \mathrm{under} \mathrm{the} \mathrm{same}$ conditions as in $\mathbf{a}$ (closed circles, $n=5$ ) and $\mathbf{b}$ (open circles, $n=5$ ), respectively

Not only cytoplasmic $\mathrm{Ca}^{2+}$ and $\mathrm{Mg}^{2+}$ but also $\mathrm{pH}$ plays a role in activation of the channels, which was confirmed by the experiments with different cytoplasmic $\mathrm{pH} 7,6.5$, and 6.0 (Fig. 7). The decrease in the cytoplasmic $\mathrm{pH}$ from 7 to 6.5 caused reduction in the open probability from 0.26 to 0.16 (Fig. 7d, upper histogram and middle histogram, respectively), but did not affect the current amplitude, which at $\mathrm{pH} 7$ and $\mathrm{pH} 6.5$ was similar (this value obtained from Gaussian fittings of histograms reached 8.07 and 8.01 $\mathrm{pA}$, respectively). After the decrease in the cytoplasmic $\mathrm{pH}$ to 6.0 , almost complete reduction of the open probability of the channels was observed $(0.005$, Fig. $7 \mathrm{~d}$, lower histogram). In turn, an increase in the vacuolar $\mathrm{pH}$ from 5 (Fig. 3) to 7 or 8 (Fig. 8a, b) did not reduce the channel activity, but caused a decrease in single channel conductance, which at $-80 \mathrm{mV}$ reached: $95.5 \pm 1.37 \mathrm{pS}(n=6)$ in $\mathrm{pH} 5,80.1 \pm 1.3 \mathrm{pS}(n=9)$ in $\mathrm{pH} 7$ and $72.9 \pm 1.8 \mathrm{pS}$ $(n=7)$ in $\mathrm{pH} 8$.

\section{Discussion}

$\mathrm{NO}_{3}{ }^{-}$transport through the tonoplast in plants is still poorly understood. The role of this transport is assigned to some members of CLC transporters. Among the wide family of these transporters, some are located in the tonoplast, like OsCLC1 and OsCLC2 from Oryza sativa (Diedhiou and Golldack 2006; Nakamura et al. 2006), GmCLC1 from Glycine max (Li et al. 2006), and AtCLCa$\mathrm{c}$ and AtCLCg from Arabidopsis thaliana (De Angeli et al. 2006; Lv et al. 2009; von der Fecht-Bartenbach et al. 2010). The activity of the AtCLCa transporter recorded in Arabidopsis thaliana (De Angeli et al. 2006) proved that this protein acts as a $\mathrm{NO}_{3}^{-} / \mathrm{H}^{+}$exchanger involved in accumulation of nitrate in the vacuole. A characteristic feature of this transporter was $\mathrm{NO}_{3}{ }^{-}$over $\mathrm{Cl}^{-}$selectivity and capability of nitrate transport into the vacuole. Channels recorded in Physcomitrella possess similar properties - the ability to carry $\mathrm{NO}_{3}{ }^{-}$currents from the cytoplasm to the vacuole (Figs. 1, 3), and $\mathrm{NO}_{3}{ }^{-}$over $\mathrm{Cl}^{-}$selectivity (Fig. 4). However, the nitrate channels in Physcomitrella differed from the $\mathrm{NO}_{3}{ }^{-} / \mathrm{H}^{+}$exchanger AtCLCa from Arabidopsis with respect to dependence of the currents on $\mathrm{pH}$. Changes in $\mathrm{pH}$ in Arabidopsis affect the reversal potential and magnitude of AtCLCa currents (De Angeli et al. 2006), whilst in Physcomitrella, the increase in the vacuolar $\mathrm{pH}$ caused a decrease in currents flowing through the channels, but not a shift in the reversal potential (Fig. 8). The lack of the influence of the $\mathrm{pH}$ gradient on the reversal potential was supported by recordings carried out at the symmetrical concentration of $\mathrm{NO}_{3}{ }^{-}$, where the reversal potential was close to zero at a $\mathrm{pH}$ gradient equal to 2 units (Figs. 1c, 3c, f). Trying to qualify the nitratepermeable channels from Physcomitrella, we decided to compare them to AtCLCa. In silico searching carried out in the NCBI databases (http://www.ncbi.nlm.nih.gov/) 
(a)

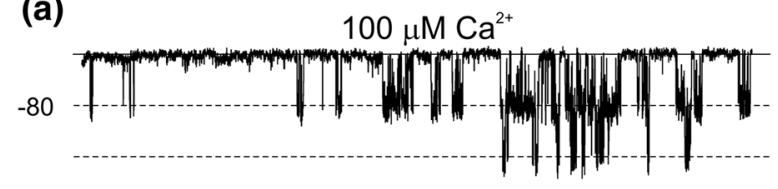

(b)

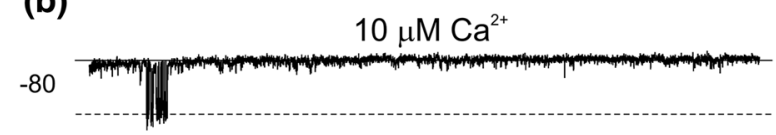

(d)

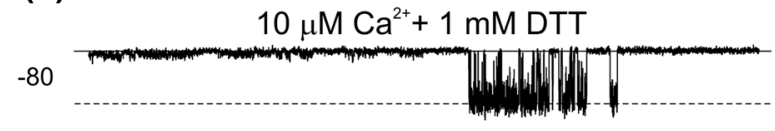

(e)

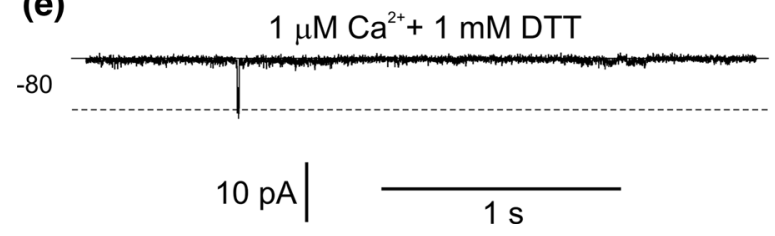

(c)

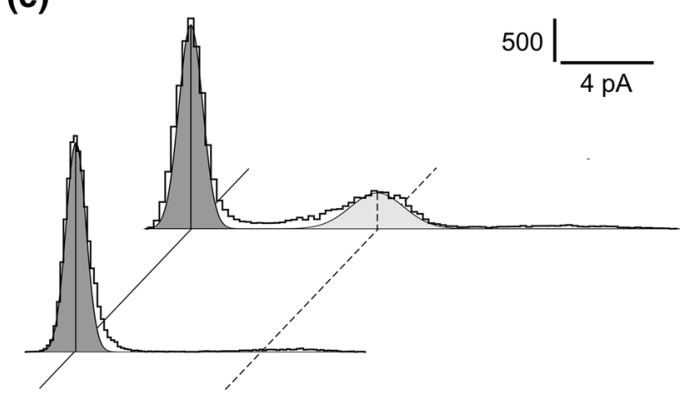

(f)

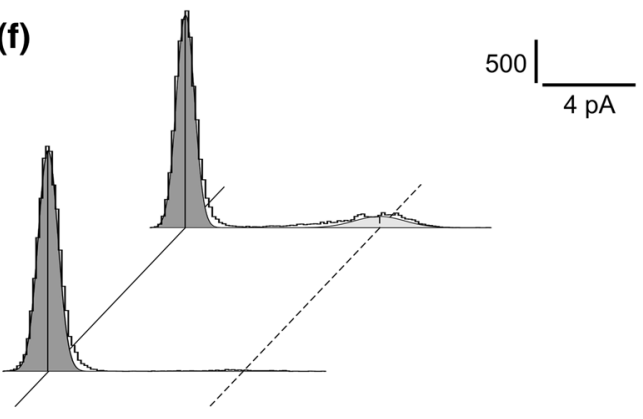

Fig. 5 Dependence of the channel activity on the cytoplasmic $\mathrm{Ca}^{2+}$ concentration recorded in the absence $(\mathbf{a}, \mathbf{b})$ and presence $(\mathbf{d}, \mathbf{e})$ of cytoplasmic DTT. a Cytoplasm-out recordings obtained in the presence of $100 \mu \mathrm{M}$ free $\mathrm{Ca}^{2+}$ at $-80 \mathrm{mV}$. The bath solution contained $200 \mathrm{mM} \mathrm{HNO}_{3}, 2 \mathrm{mM}$ EGTA, $2.08 \mathrm{mM} \mathrm{CaCl}_{2}, 2 \mathrm{mM}$ $\mathrm{MgCl}_{2}$, pH 7 (buffered by $148 \mathrm{BTP}$ ), and the pipette $200 \mathrm{mM} \mathrm{HNO}_{3}$, $2 \mathrm{mM} \mathrm{CaCl}_{2}, 2 \mathrm{mM} \mathrm{MgCl}_{2}$, pH 5 (buffered by $101 \mathrm{BTP}$ ). b Cytoplasm-out recordings obtained after reduction of the free cytoplasmic $\mathrm{Ca}^{2+}$ concentration to $10 \mu \mathrm{M}$ by replacement of the bath solution with $200 \mathrm{mM} \mathrm{HNO}_{3}, 2 \mathrm{mM}$ EGTA, $1.84 \mathrm{mM} \mathrm{CaCl}_{2}, 2 \mathrm{mM} \mathrm{MgCl}_{2}$, pH 7 (buffered by 148 BTP). c Amplitude histograms based on recordings from four patches obtained at $-80 \mathrm{mV}$ in conditions as in a (upper histogram), and b (lower histogram), respectively. d Cytoplasm-out recordings obtained in the presence of cytoplasmic $1 \mathrm{mM}$ DTT and $10 \mu \mathrm{M}$ free $\mathrm{Ca}^{2+}$. The bath solution contained $200 \mathrm{mM}$ $\mathrm{HNO}_{3}, 1 \mathrm{mM}$ DTT, $2 \mathrm{mM}$ EGTA, $1.84 \mathrm{mM} \mathrm{CaCl}$, $2 \mathrm{mM} \mathrm{MgCl}_{2}$, pH 7 (buffered by $148 \mathrm{BTP}$ ), and the pipette the same solution as used in a. e Cytoplasm-out recordings obtained after reduction of the free cytoplasmic $\mathrm{Ca}^{2+}$ concentration to $1 \mu \mathrm{M}$ by replacement of the bath solution with $200 \mathrm{mM} \mathrm{HNO}$, $1 \mathrm{mM}$ DTT, $2 \mathrm{mM}$ EGTA, $1.04 \mathrm{mM}$ $\mathrm{CaCl}_{2}, 2 \mathrm{mM} \mathrm{MgCl}$, pH 7 (buffered by $148 \mathrm{BTP}$ ). f Amplitude histograms based on recordings from four patches obtained at $80 \mathrm{mV}$ under conditions as in d (upper histogram), and e (lower histogram), respectively

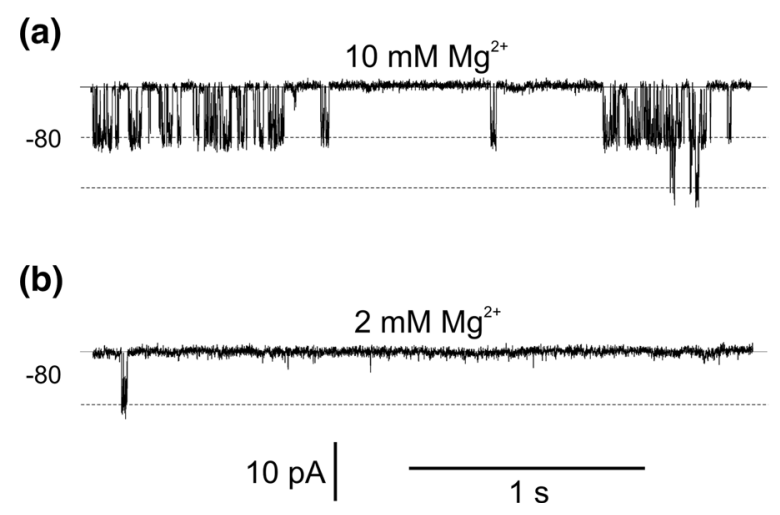

Fig. 6 Dependence of the channel activity on the cytoplasmic $\mathrm{Mg}^{2+}$ concentration. a Cytoplasm-out recordings obtained in the presence of $10 \mathrm{mM}$ free $\mathrm{Mg}^{2+}$ at $-80 \mathrm{mV}$. The bath solution contained $200 \mathrm{mM}$ $\mathrm{HNO}_{3}, 2 \mathrm{mM}$ EGTA, $10.44 \mathrm{mM} \mathrm{MgCl} 2,2 \mathrm{mM}$, pH 7 (buffered by $148 \mathrm{BTP}$ ), and the pipette $200 \mathrm{mM} \mathrm{HNO}_{3}, 2 \mathrm{mM} \mathrm{CaCl}, 2 \mathrm{mM}$ $\mathrm{MgCl}_{2}$, pH 5 (buffered by $101 \mathrm{BTP}$ ). b Cytoplasm-out recordings

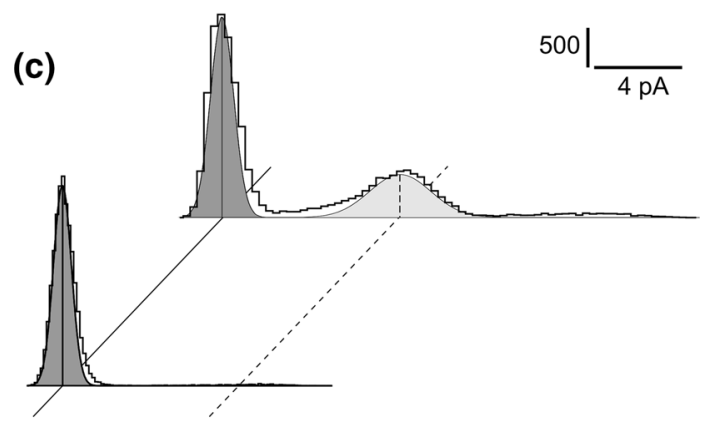

obtained after reduction of the cytoplasmic $\mathrm{Mg}^{2+}$ concentration to $2 \mathrm{mM}$ by replacement of the bath solution with $200 \mathrm{mM} \mathrm{HNO}_{3}$, $2 \mathrm{mM}$ EGTA, $2.11 \mathrm{mM} \mathrm{MgCl}_{2}$, pH 7 (buffered by $148 \mathrm{BTP}$ ). c Amplitude histograms based on recordings from four patches obtained at $-80 \mathrm{mV}$ in conditions as in a (upper histogram), and c (lower histogram), respectively 
(a)

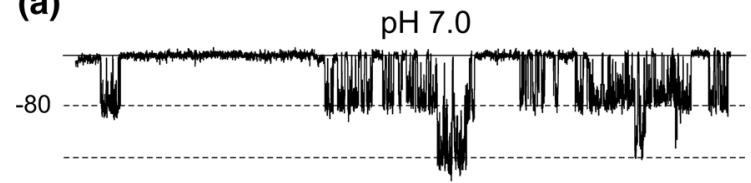

(b)

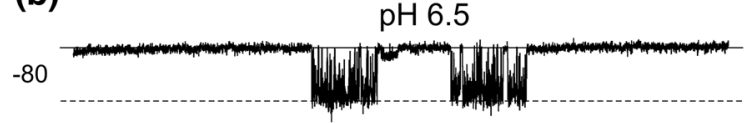

(c)

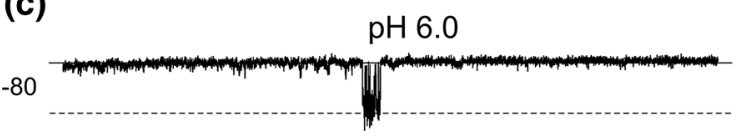

$10 \mathrm{pA}$

$1 \mathrm{~s}$

Fig. 7 Dependence of the channel activity on cytoplasmic $\mathrm{pH}$. a Cytoplasm-out recordings obtained at $-80 \mathrm{mV}$ in $200 \mathrm{mM} \mathrm{HNO}_{3}$, $2 \mathrm{mM} \mathrm{CaCl}_{2}, 2 \mathrm{mM} \mathrm{MgCl}_{2}$, pH 7 (buffered by $160 \mathrm{mM} \mathrm{BTP}$ ) in the bath and $200 \mathrm{mM} \mathrm{HNO}_{3}, 2 \mathrm{mM} \mathrm{CaCl} 2,2 \mathrm{mM} \mathrm{MgCl}_{2}, \mathrm{pH} 5$ (buffered by MES/TRIS) in the pipette. $\mathbf{b}$, $\mathbf{c}$ Cytoplasm-out recordings obtained after reduction of the cytoplasmic $\mathrm{pH}$ to 6.5 (by replacement of the

allowed finding proteins from Physcomitrella similar to AtCLCa (UniProtKB accession number P92941), among which the highest identity (49\%) was exhibited by a protein with a GenBank accession number EDQ78881. The same protein shares $49-54 \%$ similarity with AtCLCb, AtCLCc, and AtCLCg (UniProtKB accession numbers of these proteins are P92942, Q96282, and P60300, respectively). We also found high similarity of some proteins from Physcomitrella to vacuolar OsCLC1 and OsCLC2 channels from Oryza sativa (GenBank accession numbers of these proteins are BAB97267 and BAB97268, respectively). Again, a protein with a GenBank accession number EDQ78881 exhibited the highest similarity $(57 \%)$ to OsCLC1 and OsCLC2, but also two other proteins (EDQ52731, EDQ63773) with high similarity (49-51\%) were found with respect to the proteins from Oryza sativa. In silico searching was also extended to the nitrate transporter located in the tonoplast of Arabidopsis-ATNRT2.7 (UniProtKB accession number Q9LYK2). The results showed six nitrate transporters in Physcomitrella (GeneBank accession numbers: BAF42659, BAD00099, BAF42657, EDQ67083, BAF42658, EDQ67085) whose similarity to ATNRT2.7 amounts to 45-48\%.

The results of in silico research indicated that some proteins from Physcomitrella were similar to CLC-type proteins from Arabidopsis and Oryza and also to another kind of a nitrate transporter from Arabidopsis-ATNRT2.7, but it is still not possible to determine the activity of which protein was recorded in our patch-clamp experiments carried out on wild-type plants. Although the known genome of Physcomitrella gives a possibility to make

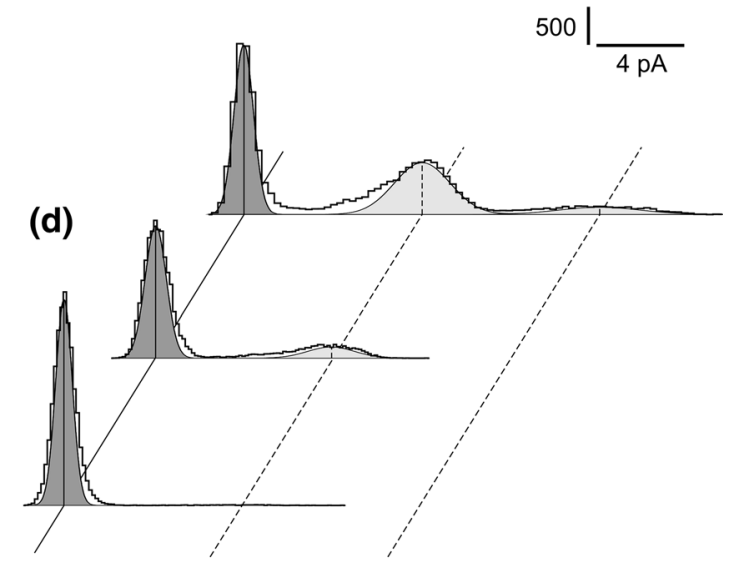

bath solution with $200 \mathrm{mM} \mathrm{HNO}_{3}, 2 \mathrm{mM} \mathrm{CaCl} 2,2 \mathrm{mM} \mathrm{MgCl}$, $131 \mathrm{mM}$ BTP) and 6.0 (by replacement of the bath solution with $200 \mathrm{mM} \mathrm{HNO}, 2 \mathrm{mM} \mathrm{CaCl}, 2 \mathrm{mM} \mathrm{MgCl}, 113 \mathrm{mM} \mathrm{BTP),}$ respectively. d Amplitude histograms based on recordings from four patches obtained at $-80 \mathrm{mV}$ in conditions as in a (upper histogram), b (middle histogram) and c (lower histogram), respectively

heterologous expression of selected ion transporters, this was not the aim of our study, which was focused on studying of $\mathrm{NO}_{3}{ }^{-}$permeability of the native tonoplast.

Interestingly, the $\mathrm{NO}_{3}{ }^{-}$permeable channels from Physcomitrella share some features with SV type channels also recorded in this plant (Koselski et al. 2013). Both channels are activated by a similar concentration of cytoplasmic $\mathrm{Ca}^{2+}$ of ca. $10 \mu \mathrm{M}$ (as shown in our Fig. 5 and by Koselski et al. 2013 in Fig. 4). Another common feature of the channels is their dependence on $\mathrm{Mg}^{2+}$ and $\mathrm{pH}$. As in the case of $\mathrm{NO}_{3}{ }^{-}$permeable channels from Physcomitrella, SV channels from higher plants are activated by cytoplasmic $\mathrm{Mg}^{2+}$ (Allen and Sanders 1996; Pei et al. 1999; Carpaneto et al. 2001) and suppressed by low cytoplasmic pH (Schulz-Lessdorf and Hedrich 1995). The activity of $\mathrm{SV}$ channels in our experiments can be discussed, because the main cation which was used-BTP, has a similar diameter $\sim 0.7 \mathrm{~nm}$ (Franciolini and Nonner 1994) as the pore of the SV channel at its narrowest place (Pottosin and Schönknecht 2007). The residual permeability of the examined channels to BTP could be the cause of the discrepancy between $\mathrm{E}_{\mathrm{NO} 3}$ and the reversal potential obtained in the $\mathrm{NO}_{3}{ }^{-}$gradient (Fig. 2f). However, in such conditions, a substantial difference occurs between the measured reversal potential $(-34.9 \mathrm{mV})$ and $\mathrm{E}_{\mathrm{BTP}}(16.2 \mathrm{mV})$. Moreover, we showed that replacement of $\mathrm{Na}^{+}$with BTP caused complete reduction of the currents flowing through SV channels (Figs. 1,2), indicating that BTP does not pass through these channels. Taking into account the strong outward rectifying behaviour of SV channels, it is doubtful that such channels would allow BTP to pass from the 
(a)
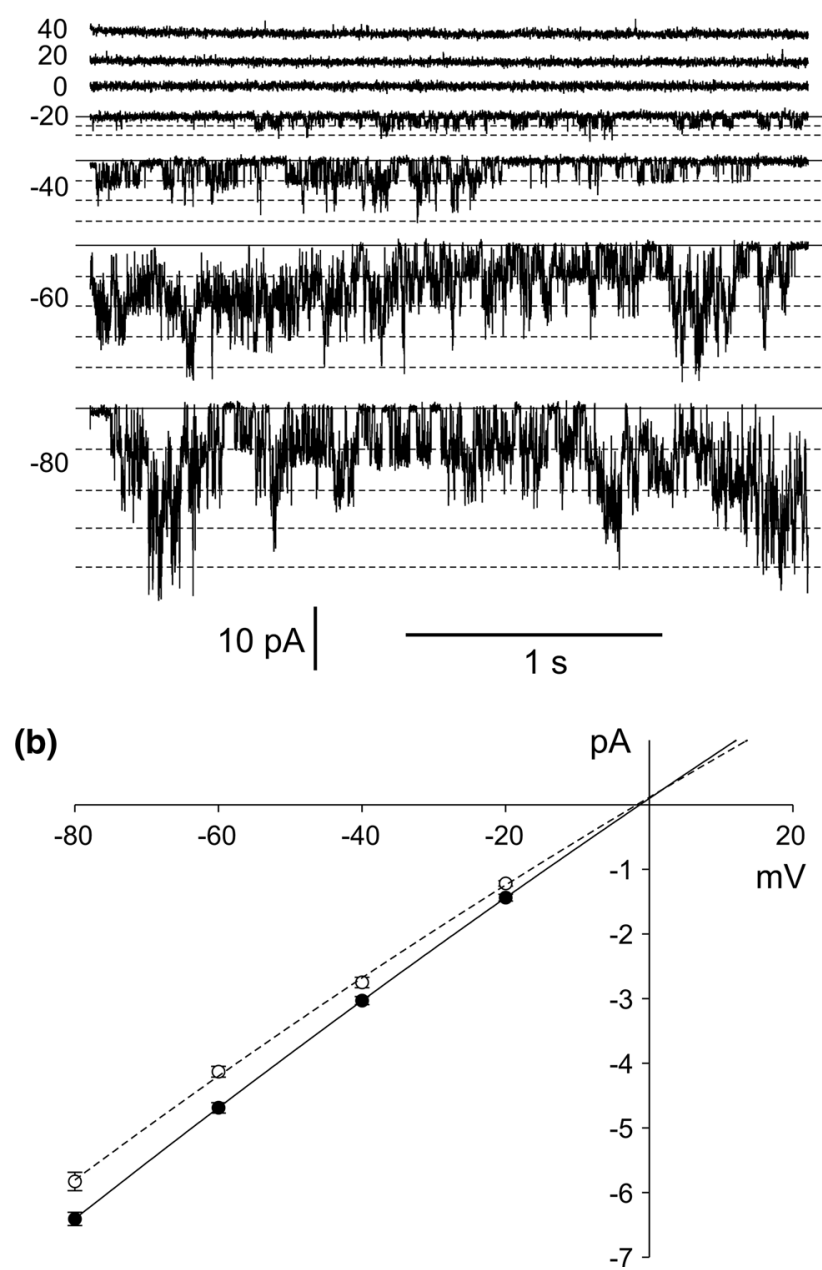

Fig. 8 Single channel activity recorded at high vacuolar $\mathrm{pH}$. a Cytoplasm-out recordings obtained at symmetrical (in the bath and in the pipette) $200 \mathrm{mM} \mathrm{HNO}_{3}, 2 \mathrm{mM} \mathrm{CaCl}_{2}, 2 \mathrm{mM} \mathrm{MgCl}_{2}, \mathrm{pH} 7$ (buffered by $160 \mathrm{mM} \mathrm{BTP}$ ). b I/V curves obtained under the same conditions as in a (closed circles and solid line, $n=9$ ) and after increasing the vacuolar $\mathrm{pH}$ to 8 by application of $200 \mathrm{mM} \mathrm{HNO}_{3}$, $2 \mathrm{mM} \mathrm{CaCl}_{2}, 2 \mathrm{mM} \mathrm{MgCl}_{2}, 193 \mathrm{mM}$ BTP in the pipette (open circles and dashed line, $n=7$ ), respectively

vacuole to the cytoplasm, since at a lower concentration of this cation on the vacuolar side (101 $\mathrm{mM}$ in comparison to $160 \mathrm{mM}$ added on the cytoplasmic side, Fig. 3a) we recorded mainly negative inward currents.

The discrepancy between the measured reversal potential and $\mathrm{E}_{\mathrm{NO} 3}$ can indicate contribution of other than $\mathrm{NO}_{3}{ }^{-}$ ions in the recorded currents. One of the ions that could affect the reversal potential was $\mathrm{Cl}^{-}$added in a symmetrical concentration $(8 \mathrm{mM})$ on both sides of the tonoplast (Fig. 3). The permeability of the channels from Physcomitrella to $\mathrm{Cl}^{-}$was confirmed by recordings of the channel activity in the absence of $\mathrm{NO}_{3}{ }^{-}$(Fig. 4a). In the same experiment, replacement of $\mathrm{Cl}^{-}$to $\mathrm{NO}_{3}{ }^{-}$on the cytoplasmic side of the tonoplast (Fig. $4 \mathrm{~b}$ ) proved that the channels were approximately three times more permeable to $\mathrm{NO}_{3}{ }^{-}$than $\mathrm{Cl}^{-}$. In the experiments verifying the channel selectivity (Fig. 3), the low permeability of the channel to $\mathrm{Cl}^{-}$and its much lower concentration than $\mathrm{NO}_{3}{ }^{-}$, allowed us to assume that the effect of $\mathrm{Cl}^{-}$on the reversal potential, if it occurs, should not be higher than a few millivolts. A much higher difference between $\mathrm{E}_{\mathrm{NO} 3}$ and the reversal potential was observed in our experiments $(16.7 \mathrm{mV})$.

Up to now, there have been insufficient data showing the activity of single $\mathrm{NO}_{3}{ }^{-}$permeable channels in the plant vacuole and it is hard to classify the channels from Physcomitrella. Only some of the regulatory mechanisms of Physcomitrella channels are common with these described earlier in vacuolar anion channels from different plants. For instance, strong dependence on cytoplasmic $\mathrm{Mg}^{2+}$ and weaker dependence on some other divalent cytoplasmic cations (including $\mathrm{Ca}^{2+}$ ) were observed during patch-clamp recordings of vacuolar anion channels from the liverwort Conocephalum conicum (Trebacz et al. 2007). These channels were also selective to $\mathrm{NO}_{3}{ }^{-}$and, in comparison to other tested anions, the presence of $\mathrm{NO}_{3}{ }^{-}$in the cytoplasm evoked the highest density of currents carried by the channels. Cytoplasmic $\mathrm{Ca}^{2+}$ plays a crucial role also in activation of vacuolar chloride channels recorded in the whole-vacuole configuration in a higher plant, Vicia faba (Pei et al. 1996). In this plant, vacuolar anion channels are activated by CDPK (Calcium-Dependent Protein Kinase), acting together with $\mathrm{Ca}^{2+}$. Cytoplasmic $\mathrm{Ca}^{2+}$ together with $\mathrm{Zn}^{2+}$ also activates chloride channels in tobacco vacuoles (Ping et al. 1992). As in the case of the $\mathrm{NO}_{3}{ }^{-}$permeable channels from Physcomitrella, chloride channels in tobacco were silent during the activity of channels permeable to $\mathrm{K}^{+}$. The calcium-dependent mechanism of the $\mathrm{H}^{+} / \mathrm{NO}_{3}{ }^{-}$antiport operates in the tonoplast of cucumber root cells (Migocka et al. 2013), where phosphorylation of a tonoplast antiporter involving Ca-dependent staurosporine-sensitive protein kinase may be involved in stimulation of the $\mathrm{H}^{+} / \mathrm{NO}_{3}{ }^{-}$antiport. Another feature of the $\mathrm{NO}_{3}{ }^{-}$permeable channels from Physcomitrella was the dependence of the channel conductance on cytosolic nitrate (Fig. 3f). A process of vacuolar anion selective channel regulation by chloride was found in Beta vulgaris (Plant et al. 1994), but in the case of these channels increasing vacuolar but not cytoplasmic chloride induced an increase in the inward currents carried by nitrate, acetate, and phosphate.

In this work, we studied dependence of $\mathrm{NO}_{3}{ }^{-}$permeable channels from Physcomitrella on the cytoplasmic concentration of $\mathrm{Ca}^{2+}, \mathrm{Mg}^{2+}$ and $\mathrm{pH}-$ factors whose fluctuations play a role in some intracellular processes. Among the three factors mentioned, only $\mathrm{Ca}^{2+}$ operates in non-physiological concentrations, that is why participation of this 
ion in accumulation of $\mathrm{NO}_{3}{ }^{-}$in the vacuole is questionable. Higher than the physiological cytoplasmic calcium concentration is also required for activation of vacuolar calcium-dependent channels from other plants, e.g. SV channels recorded in Arabidopsis thaliana in the presence of cytoplasmic $\mathrm{Ca}^{2+}$ exceeding $10 \mu \mathrm{M}$ (Schulze et al. 2011) or SV channels from guard cells of Vicia faba being inactive at a calcium concentration lower than $10 \mu \mathrm{M}$ (Pei et al. 1999). Some clues about the possibility of SV channel activation at lower and more physiological concentrations of cytoplasmic $\mathrm{Ca}^{2+}$ can be found in papers proving the increase in the channel activity as a result of (1) a synergistic effect of cytoplasmic $\mathrm{Ca}^{2+}$ and $\mathrm{Mg}^{2+}$ (Pei et al. 1999), (2) a decrease in vacuolar $\mathrm{Ca}^{2+}$ (Pottosin et al. 1997; Koselski et al. 2013), (3) an increase of cytoplasmic or vacuolar $\mathrm{pH}$ (Schulz-Lessdorf and Hedrich 1995), (4) addition of reducing agents (Carpaneto et al. 1999; ScholzStarke et al. 2004). Activated by high and non-physiological concentrations of cytoplasmic $\mathrm{Ca}^{2+}$, channels are present not only in plant vacuoles. In the vacuole of yeast Saccharomyces cerevisiae Bertl and Slayman (1990) recorded cation-selective channels activated by cytoplasmic $\mathrm{Ca}^{2+}$ concentrations $\geq 1 \mathrm{mM}$. Similar to plant $\mathrm{SV}$ channels, these channels were also activated by reducing agents. Dependence of the vacuolar channels from Saccharomyces cerevisiae coded by a TRP-like (transient receptor potential) gene on the high $1 \mathrm{mM}$ concentration of cytoplasmic $\mathrm{Ca}^{2+}$ was confirmed by Palmer et al. (2001).

The results of our study revealed that even at elevated concentrations of cytoplasmic $\mathrm{Ca}^{2+}(1 \mu \mathrm{M})$ and the presence of an antioxidant-DTT (Fig. 5e), whose effectiveness in activation of calcium- and voltage-dependent channels was confirmed in plant vacuolar channels (Carpaneto et al. 1999; Paganetto et al. 2001; Scholz-Starke et al. 2004), the $\mathrm{NO}_{3}{ }^{-}$permeable channels from Physcomitrella remain closed. Although these studies revealed involvement of redox status in activation of the channels by cytoplasmic calcium, it is probable that another, so far unknown factor(s) can be essential for the in vivo functioning of the channel. The two other factors tested, $\mathrm{Mg}^{2+}$ and $\mathrm{pH}$, affected the channel activity at the physiological range of the concentrations. $\mathrm{Mg}^{2+}$ and $\mathrm{pH}$ can cooperate in regulation of these channels. In a complex with ATP, $\mathrm{Mg}^{2+}$ is responsible for driving proton pumps and creating a proton-motive force through the cell membrane (by $\mathrm{H}^{+}$ATPase) and the tonoplast (by V-ATPase) (Maeshima and Nakanishi 2002). For example, Hanstein et al. (2011) proved that the activity of $\mathrm{H}^{+}$-ATPase in maize decreased in the presence of $\mathrm{Mg}^{2+}$-free ATP and was restored after increasing the $\mathrm{Mg}^{2+}$ concentration. The influence of the free $\mathrm{Mg}^{2+}$ concentration on the stability and activity of $\mathrm{V}-\mathrm{PP}_{\mathrm{i}}$ ase, another tonoplast $\mathrm{H}^{+}$pump, was confirmed in mung bean vacuoles (Maeshima 1991). Some importance in $\mathrm{Mg}^{2+}$ and $\mathrm{H}^{+}$balancing can be also assigned to the $\mathrm{Mg}^{2+} / \mathrm{H}^{+}$vacuolar exchanger characterised in Arabidopsis thaliana (Shaul et al. 1999).

$\mathrm{NO}_{3}{ }^{-}$permeable channels recorded in Physcomitrella share some similarities with aluminum-activated malate transporters (ALMTs). Two members of the ALMT family were identified in the plant vacuole. The first, AtALMT9, was initially characterised in the vacuole of Arabidopsis thaliana (Kovermann et al. 2007; De Angeli et al. 2013b) and then in Vitis vinifera (De Angeli et al. 2013a). The second member of ALMT recorded in Arabidopsis was AtALMT6 (Meyer et al. 2011). A common feature of $\mathrm{NO}_{3}{ }^{-}$permeable channels from Physcomitrella and malate transporters is strong rectification of the currents in the same direction. Moreover, AtALMT6 is activated in the presence of $100 \mu \mathrm{M}$ cytoplasmic calcium-a similar concentration of calcium ions activates $\mathrm{NO}_{3}{ }^{-}$permeable channels from Physcomitrella. The patch-clamp measurements of AtALMT9 activity proved also that these transporters are chloridepermeable channels activated by cytoplasmic malate (De Angeli et al. 2013b). In contrast, there are no published data demonstrating nitrate fluxes through ALMTs. There is also another feature that differentiates the channels recorded in Physcomitrella from ALMTs-the much lower conductance of AtALMT9 (32 pS recorded in symmetrical $100 \mathrm{mM} \mathrm{Cl}^{-}$) with respect to channels from Physcomitrella (95.5 pS recorded in symmetrical $200 \mathrm{mM} \mathrm{NO}_{3}{ }^{-}$). It should be mentioned that much lower conductance $(3 \mathrm{pS}$ recorded in the presence of 100 and $10 \mathrm{mM}$ malate/BTP on the cytoplasmic and vacuolar side, respectively) possesses an inward-rectifying vacuolar malate channel of a plant showing crassulacean acid metabolism (CAM), Kalanchoё daigremontiana (Hafke et al. 2003).

In conclusion, this study describes a possible pathway for nitrate transport from the cytoplasm to the vacuole, based on the activity of $\mathrm{NO}_{3}{ }^{-}$permeable channels. Although accumulation of nitrate in the vacuole via CLCtype proteins has been proved earlier (De Angeli et al. 2006), the regulation of this process is still poorly understood. In this work, we focused on studying of the regulatory mechanism of $\mathrm{NO}_{3}{ }^{-}$permeable channels from Physcomitrella by some factors involved in cell signalling (e.g. the level of cytoplasmic $\mathrm{Ca}^{2+}$ ) or in secondary transport through the tonoplast (facilitated by the $\mathrm{pH}$ gradient). We believe that this work fills a gap in our knowledge about vacuolar transport of nitrate in plants, especially concerning the functioning of nitrate-permeable channels.

Author contribution Mateusz Koselski conceived and designed research, conducted experiments, analyzed data, 
and wrote the main part of the manuscript. Halina Dziubinska participated in writing the manuscript and its reviewing. Aleksandra Seta-Koselska participated in preparation of plant material and reviewed the manuscript. Kazimierz Trebacz reviewed the manuscript and received a grant NCN (National Science Centre) no. 2013/09/B/NZ1/ 01052. All authors read and approved the manuscript.

Acknowledgments This work was supported by NCN (National Science Centre) Grant No. 2013/09/B/NZ1/01052.

Open Access This article is distributed under the terms of the Creative Commons Attribution License which permits any use, distribution, and reproduction in any medium, provided the original author(s) and the source are credited.

\section{References}

Accardi A, Miller C (2004) Secondary active transport mediated by a prokaryotic homologue of $\mathrm{ClC} \mathrm{Cl}^{-}$channels. Nature 427:803-807. doi:10.1038/nature02314

Accardi A, Walden M, Nguitragool W, Jayaram H, Williams C, Miller C (2005) Separate ion pathways in a $\mathrm{Cl}^{-} / \mathrm{H}^{+}$exchanger. J Gen Physiol 126:563-570. doi:10.1085/jgp.200509417

Allen GJ, Sanders D (1996) Control of ionic currents in guard cell vacuoles by cytosolic and luminal calcium. Plant J 10:1055-1069

Amtmann A, Sanders D (1997) A unified procedure for the correction of liquid junction potentials in patch clamp experiments on endoand plasma membranes. J Exp Bot 48:361-364. doi:10.1093/jxb/ 48.Special_Issue.361

Bertl A, Slayman CL (1990) Cation-selective channels in the vacuolar membrane of Saccharomyces: dependence on calcium, redox state, and voltage. Proc Natl Acad Sci USA 87:7824-7828. doi:10.1073/pnas.87.20.7824

Bertl A, Blumwald E, Coronado R, Eisenberg R, Findlay G, Gradmann D, Hille B, Kohler K, Kolb HA, Macrobbie E, Meissner G, Miller C, Neher E, Palade P, Pantoja O, Sanders D, Schroeder J, Slayman C, Spanswick R, Walker A, Williams A (1992) Electrical measurements on endomembranes. Science 258:873-874

Bush DS (1995) Calcium regulation in plant cells and its role in signaling. Annu Rev Plant Physiol Plant Mol Biol 46:95-122. doi:10.1146/annurev.pp.46.060195.000523

Carpaneto A, Cantu AM, Gambale F (1999) Redox agents regulate ion channel activity in vacuoles from higher plant cells. FEBS Lett 442:129-132. doi:10.1016/s0014-5793(98)01642-1

Carpaneto A, Cantu AM, Gambale F (2001) Effects of cytoplasmic $\mathrm{Mg}^{2+}$ on slowly activating channels in isolated vacuoles of Beta vulgaris. Planta 213:457-468

Chopin F, Orsel M, Dorbe M-F, Chardon F, Truong H-N, Miller AJ, Krapp A, Daniel-Vedele F (2007) The Arabidopsis ATNRT2.7 nitrate transporter controls nitrate content in seeds. Plant Cell 19:1590-1602. doi:10.1105/tpc.107.050542

De Angeli A, Monachello D, Ephritikhine G, Frachisse JM, Thomine S, Gambale F, Barbier-Brygoo H (2006) The nitrate/proton antiporter AtCLCa mediates nitrate accumulation in plant vacuoles. Nature 442:939-942. doi:10.1038/nature05013

De Angeli A, Baetz U, Francisco R, Zhang J, Chaves MM, Regalado A (2013a) The vacuolar channel VvALMT9 mediates malate and tartrate accumulation in berries of Vitis vinifera. Planta 238:283-291. doi:10.1007/s00425-013-1888-y
De Angeli A, Zhang J, Meyer S, Martinoia E (2013b) AtALMT9 is a malate-activated vacuolar chloride channel required for stomatal opening in Arabidopsis. Nat Commun. doi:10.1038/ncomms 2815

Diedhiou C, Golldack D (2006) Salt-dependent regulation of chloride channel transcripts in rice. Plant Sci 170:793-800. doi:10.1016/j. plantsci.2005.11.014

Franciolini F, Nonner W (1994) Anion-cation interactions in the pore of neuronal background chloride channels. J Gen Physiol 104:711-723. doi:10.1085/jgp.104.4.711

Hafke JB, Hafke Y, Smith JAC, Luttge U, Thiel G (2003) Vacuolar malate uptake is mediated by an anion-selective inward rectifier. Plant J 35:116-128. doi:10.1046/j.1365-313X.2003.01781.x

Hanstein S, Wang X, Qian X, Friedhoff P, Fatima A, Shan Y, Feng K, Schubert $\mathrm{S}$ (2011) Changes in cytosolic $\mathrm{Mg}^{2+}$ levels can regulate the activity of the plasma membrane $\mathrm{H}^{+}$-ATPase in maize. Biochem J 435:93-101. doi:10.1042/bj20101414

Hechenberger M, Schwappach B, Fischer WN, Frommer WB, Jentsch TJ, Steinmeyer K (1996) A family of putative chloride channels from Arabidopsis and functional complementation of a yeast strain with a CLC gene disruption. J Biol Chem 271:3363233638

Jossier M, Kroniewicz L, Dalmas F, Le Thiec D, Ephritikhine G, Thomine S, Barbier-Brygoo H, Vavasseur A, Filleur S, Leonhardt N (2010) The Arabidopsis vacuolar anion transporter, AtCLCc, is involved in the regulation of stomatal movements and contributes to salt tolerance. Plant J 64:563-576. doi:10. 1111/j.1365-313X.2010.04352.x

Koselski M, Trebacz K, Dziubinska H (2013) Cation-permeable vacuolar ion channels in the moss Physcomitrella patens: a patch-clamp study. Planta 238:357-367. doi:10.1007/s00425013-1902-4

Kovermann P, Meyer S, Hoertensteiner S, Picco C, Scholz-Starke J, Ravera S, Lee Y, Martinoia E (2007) The Arabidopsis vacuolar malate channel is a member of the ALMT family. Plant $\mathbf{J}$ 52:1169-1180. doi:10.1111/j.1365-313X.2007.03367.x

Leigh RA, Wyn Jones RG (1986) Cellular compartmentation in plant nutrition: the selective cytoplasm and the promiscuous vacuole. In: Tinker B, Lauchli A (eds) Adv Plant Nutr 2. Praeger Scientific, New York, p 249-279

Li WYF, Wong FL, Tsai SN, Phang TH, Shao GH, Lam HM (2006) Tonoplast-located $\mathrm{GmCLCl}$ and $\mathrm{GmNHX1}$ from soybean enhance $\mathrm{NaCl}$ tolerance in transgenic bright yellow (BY)-2 cells. Plant Cell Environ 29:1122-1137. doi:10.1111/j.13653040.2005.01487.x

Lurin C, Geelen D, BarbierBrygoo H, Guern J, Maurel C (1996) Cloning and functional expression of a plant voltage-dependent chloride channel. Plant Cell 8:701-711

Lv QD, Tang RJ, Liu H, Gao XS, Li YZ, Zheng HQ, Zhang HX (2009) Cloning and molecular analyses of the Arabidopsis thaliana chloride channel gene family. Plant Sci 176:650-661. doi:10.1016/j.plantsci.2009.02.006

Maeshima M (1991) $\mathrm{H}^{+}$-translocating inorganic pyrophosphatase of plant vacuoles - inhibitory by $\mathrm{Ca}^{2+}$, stabilization by $\mathrm{Mg}^{2+}$ and immunological comparison with other inorganic pyrophosphatases. Eur J Biochem 196:11-17. doi:10.1111/j.1432-1033.1991. tb15779.x

Maeshima M, Nakanishi Y (2002) $\mathrm{H}^{+}$-ATPase and $\mathrm{H}^{+}$-PPase in the vacuolar membrane: physiology and molecular biology. In: Rengel $\mathrm{Z}$ (ed) Handbook of plant growth $\mathrm{pH}$ as the master variable. Marcel Dekker, New York-Basel, pp 23-47

Marmagne A, Vinauger-Douard M, Monachello D, de Longevialle AF, Charon C, Allot M, Rappaport F, Wollman F-A, BarbierBrygoo H, Ephritikhine G (2007) Two members of the Arabidopsis CLC (chloride channel) family, AtCLCe and AtCLCf, are associated with thylakoid and Golgi membranes, respectively. J Exp Bot 58:3385-3393. doi:10.1093/jxb/erm187 
Meyer S, Scholz-Starke J, De Angeli A, Kovermann P, Burla B, Gambale F, Martinoia E (2011) Malate transport by the vacuolar AtALMT6 channel in guard cells is subject to multiple regulation. Plant J 67:247-257. doi:10.1111/j.1365-313X.2011. 04587.x

Migocka M, Warzybok A, Papierniak A, Klobus G (2013) $\mathrm{NO}_{3}{ }^{-} / \mathrm{H}^{+}$ antiport in the tonoplast of cucumber root cells is stimulated by nitrate supply: evidence for a reversible nitrate-induced phosphorylation of vacuolar $\mathrm{NO}_{3}{ }^{-} / \mathrm{H}^{+}$antiport. Plos One. doi:10. 1371/journal.pone.0073972

Miller C, White MM (1980) A voltage-dependent chloride conductance channel from Torpedo electroplax membrane. Ann NY Acad Sci 341:534-551. doi:10.1111/j.1749-6632.1980.tb47197.x

Nakamura A, Fukuda A, Sakai S, Tanaka Y (2006) Molecular cloning, functional expression and subcellular localization of two putative vacuolar voltage-gated chloride channels in rice (Oryza sativa L.). Plant Cell Physiol 47:32-42. doi:10.1093/pcp/ pci220

Paganetto A, Carpaneto A, Gambale F (2001) Ion transport and metal sensitivity of vacuolar channels from the roots of the aquatic plant Eichhornia crassipes. Plant Cell Environ 24:1329-1336. doi:10.1046/j.1365-3040.2001.00777.x

Palmer CP, Zhou XL, Lin JY, Loukin SH, Kung C, Saimi Y (2001) A TRP homolog in Saccharomyces cerevisiae forms an intracellular $\mathrm{Ca}^{2+}$-permeable channel in the yeast vacuolar membrane. Proc Natl Acad Sci USA 98:7801-7805. doi:10.1073/pnas. 141036198

Pei ZM, Ward JM, Harper JF, Schroeder JI (1996) A novel chloride channel in Vicia faba guard cell vacuoles activated by the serine/ threonine kinase, CDPK. EMBO J 15:6564-6574

Pei ZM, Ward JM, Schroeder JI (1999) Magnesium sensitizes slow vacuolar channels to physiological cytosolic calcium and inhibits fast vacuolar channels in fava bean guard cell vacuoles. Plant Physiol 121:977-986

Picollo A, Pusch M (2005) Chloride/proton antiporter activity of mammalian CLC proteins $\mathrm{ClC}-4$ and $\mathrm{ClC}-5$. Nature 436:420-423. doi:10.1038/nature 03720

Ping Z, Yabe I, Muto S (1992) Identification of $\mathrm{K}^{+}, \mathrm{Cl}^{-}$, and $\mathrm{Ca}^{2+}$ channels in the vacuolar membrane of tobacco cell suspension cultures. Protoplasma 171:7-18. doi:10.1007/bf01379275

Plant PJ, Gelli A, Blumwald E (1994) Vacuolar chloride regulation of an anion-selective tonoplast channel. J Membrane Biol 140:1-12
Pottosin II, Schönknecht G (2007) Vacuolar calcium channels. J Exp Bot 58:1559-1569. doi:10.1093/jxb/erm035

Pottosin II, Tikhonova LI, Hedrich R, Schönknecht G (1997) Slowly activating vacuolar channels can not mediate $\mathrm{Ca}^{2+}$-induced $\mathrm{Ca}^{2+}$ release. Plant J 12:1387-1398

Reski R, Abel WO (1985) Induction of budding on chloronemata and caulonemata of the moss, Physcomitrella patens, using isopentenyladenine. Planta 165:354-358

Scholz-Starke J, De Angeli A, Ferraretto C, Paluzzi S, Gambale F, Carpaneto A (2004) Redox-dependent modulation of the carrot SV channel by cytosolic pH. FEBS Lett 576:449-454. doi:10. 1016/j.febslet.2004.09.052

Schulze C, Sticht H, Meyerhoff P, Dietrich P (2011) Differential contribution of EF-hands to the $\mathrm{Ca}^{2+}$-dependent activation in the plant two-pore channel TPC1. Plant J 68:424-432. doi:10.1111/j. 1365-313X.2011.04697.x

Schulz-Lessdorf B, Hedrich R (1995) Protons and calcium modulate SV-type channels in the vacuolar-lysosomal compartment channel interaction with calmodulin inhibitors. Planta 197:655-671

Shaul O, Hilgemann DW, de-Almeida-Engler J, Van Montagu M, Inze D, Galili G (1999) Cloning and characterization of a novel $\mathrm{Mg}^{2+} / \mathrm{H}^{+}$exchanger. EMBO J 18:3973-3980. doi:10.1093/ emboj/18.14.3973

Steinmeyer K, Ortland C, Jentsch TJ (1991) Primary structure and functional expression of a developmentally regulated skeletal muscle chloride channel. Nature 354:301-304. doi:10.1038/ $354301 \mathrm{a} 0$

Trebacz K, Schönknecht G (2000) Simple method to isolate vacuoles and protoplasts for patch-clamp experiments. Protoplasma 213:39-45

Trebacz K, Schönknecht G, Dziubińska H, Hanaka A (2007) Characteristics of anion channels in the tonoplast of the liverwort Conocephalum conicum. Plant Cell Physiol 48:1747-1757. doi:10.1093/pcp/pcm 147

von der Fecht-Bartenbach J, Bogner M, Dynowski M, Ludewig U (2010) CLC-b-mediated $\mathrm{NO}_{3}{ }^{-} / \mathrm{H}^{+}$exchange across the tonoplast of Arabidopsis vacuoles. Plant Cell Physiol 51:960-968. doi:10. 1093/pcp/pcq062 